\title{
Contribution of Entrepreneurship Attitudes to Work Readiness of Participants in Vocational Education Course at SKB Kota Padang
}

\author{
Solfema \\ Department of Non Formal Education, Faculty of \\ Education \\ Universitas Negeri Padang \\ Padang, Indonesia \\ solfema@fip.unp.ac.id
}

\author{
Syafruddin Wahid \\ Department of Non Formal Education, Faculty of \\ Education \\ Universitas Negeri Padang \\ Padang, Indonesia \\ syafruddinwahid@fip.unp.ac.id
}

\author{
Alim Harun Pamungkas \\ Department of Non Formal Education, Faculty of Education \\ Universitas Negeri Padang \\ Padang, Indonesia \\ alimharun@fip.unp.ac.id
}

\begin{abstract}
The era of globalization requires all parties to improve the quality of their competence through education, both of formal education, non-formal education or informal. Skill education (PK) is one of all of the activities from non-formal education who can answer these demands. But, as we know from the phenomenon has happened, many of PK graduates, they're not ready to work based on their ability that they have. Suspected unpreparedness is caused by entrepreneurial attitudes. Therefore, the purpose of this research is to see the relationship and entrepreneurial attitude with and towards the work readiness of PK course participants at the Padang City Learning Activities Studio (SKB). This research used a correlational research design. The sample that used is technique random sampling, as many as $80 \%$ of the population, that consisted of 32 people. Data were analyzed using simple regression analysis techniques. Based on research findings, be concluded that entrepreneurial attitude is significantly related to work readiness of PK course participants with a rX price of 0.782. Thus, it is known that entrepreneurial attitudes contribute significantly to the work readiness of PK course participants. Accordingly, there is a need for efforts to foster entrepreneurial attitudes by all parties involved in the educational record activities.
\end{abstract}

Keywords: entrepreneurial attitudes, working readiness, vocational education, learning activities studio

\section{INTRODUCTION}

The quality of human resources has a strategic role in meeting the demands of national development in various fields, therefore, the quality of human resources is closely related to the progress and prosperity of a nation. To make quality HUMAN RESOURCES, starting from the field of education, both formal and non-formal education, especially the results of its graduates must be able to compete with other nations [1].

The characteristic of era globalization is by quality competition. Such matter, demands all partis in various fields and sectors of development to always improve their competence, especially thorugh educational activities. Education plays an important role in improving the quality of a nation, including non-formal education. On of the form of the activities non-formal education which prepares workers who are expected to enter the workforce is the Institute of Courses and Training (LKP) [2]. Among LKP managed by the Directorate of Course and Training Development, the Directorate General of Early Childhood Education, Non-Formal and Informal, the Ministry of Education and Culture is the LKP that organizes the Skills Education (PK) program.

One of the things underlying this program is that Indonesia faces significant unemployment problems. In early February 2010, unemployment amounted to around
8.32 million people, and an additional new workforce averaged 1.7 million people per year who came from school dropouts and high school and vocational school children who did not go on to college, as well as college graduates that doesn't work yet. Therefore, in line with the policy of aligning education with the world of work, courses and training programs have been strived to improve access and quality since 2006 , at least if the level of success of each program is seen in the placement of graduates for work and / or entrepreneurship.

But from the phenomenon which is observed, know that many of graduate of PK program who don't work based on their abilities they find [3]. Many of them are working, but not comfortable with their work, even many of them are still not entering the workforce

The unpreparedness of someone in the world of work is influenced by many factors, including achievement motivation factors [4]. Entrepreneurship insight factor as a factor that has contributed to work readiness. Entrepreneurs are those who are able to move the community's economy forward, including those who dare to take risks, manage activities, manage capital or resources, and those who have creative and innovative responses to the opportunities that exist [5]. Therefore, people who have high entrepreneurial attitudes will be persistent in the work [6]. 
According to [7] about working readiness is in an effort to have skills that are appropriate to the needs of the community so that course participants after graduation can later be absorbed by the world of work. While Baiti, Abdullah, \& Rochwidowati (2017), focuses on the understanding of work readiness on personal traits, such as the nature of workers and the defense mechanisms needed, not only to get a job, but more than that, namely to maintain a job. Work readiness includes everything that is owned by someone, both the ability and behavior needed for each job. In this sense, work readiness refers more to a person's personal factors rather than to external factors or the environment [9].

So, the conclude that the someone who have working readiness not only people who has been work, but someone who has not worked can also be said to have work readiness if the personal characteristics that are found in the person who has an argument. So, people who already have a set of abilities and self-behaviors needed in each job can be said to be able to work, because it meets the criteria for work readiness

Based on the explanation above, the purpose this research is for : (1) Obtain an overview of entrepreneurship attitudes of Padang City PK course participants; (2) Describe the work readiness of Padang City PK course participants; (3) Knowing how big is the correlation between entrepreneurship attitudes and work readiness of Padang City PK course participants; and (4) Knowing how much the entrepreneurial attitude contributes to the work readiness of Padang City PK course participants.

\section{METHOD}

This research is expost fakto research, who describe events that happened as they were. This research design is a correlational research $\neg$ design. In connection with the research design used, it will be seen the relationship between independent variables (predictors), that is entrepreneurial attitude $(\mathrm{X})$ with the dependent variable (criterium), that is the level of work readiness $(\mathrm{Y})$, and find the amount of contribution to the dependent variable.

Before we see the relationship between entrepreneurship attitude (X) with the level of work readiness $(\mathrm{Y})$ and finding the amount of entrepreneurial attitude contribution $(\mathrm{X})$ to the level of work readiness $(\mathrm{Y})$, first try to get a picture of the entrepreneurial attitude variable work readiness of PK course participants in West Sumatra.

Population this research is all of the participant PK at Kota Padang in 2015 were 40 people. While sampling uses a random area sampling technique (non-stratified group sampling technique) by drawing a sample of $80 \%$ of the population, so the sample is 32 people. This is in accordance with the characteristics of the trainees from various districts in the Kota Padang.

Based on the data needs, to be disclosed, the instrument used to collect data is a questionnaire using a Likert model measurement scale with a scale of 4 , with alternative answers Strongly Agree (SS), Agree (S), Disagree (TS), and Strongly Disagree (STS).
Based on the types of data analysis, the analysis technique used is simple regression. Simple linear regression analysis technique is one of the regression methods that can be used as a statistical inference tool to determine the effect of independent variables on the dependent variable [10].

\section{RESULTS AND DISCUSSION}

From this section, it will be stated (1) A description of the entrepreneurial attitudes of Padang City PK course participants; (2) A description of the work readiness of Padang City PK course participants; (3) Correlation between entrepreneurship attitudes and work readiness of Padang PK PK course participants; and (4) Contribution of entrepreneurial attitudes to work readiness of Padang PK PK course participants.

\section{A. Achievement Motivation of PK course participants in Padang}

Based on the result of data analysis, we can conlude that the achievement motivation of PK couse participants in Padang, look at Table 1.

Table 1

Achievement Motivation of PK course participants in Padang

\begin{tabular}{|c|c|c|c|c|}
\hline No. & $\begin{array}{c}\text { Interval } \\
\text { Score }\end{array}$ & Criteria & Frequency & $\%$ \\
\hline 1 & $55-68$ & Very high & 4 & 12 \\
\hline 2 & $41-54$ & High & 9 & 28 \\
\hline 3 & $27-40$ & Low & 14 & 44 \\
\hline 4 & $13-26$ & Very low & 5 & 16 \\
\hline \multicolumn{3}{|c|}{ total } & 32 & 100 \\
\hline
\end{tabular}

Based on Table 1, it can be obtained that the entrepreneurial attitude of PK course participants in Padang City is low. This is evidenced by the large number of respondents, i.e. 14 out of 32 respondents or $44 \%$ who stated that they agreed with statements that showed low entrepreneurial attitudes. On the other hand, only 4 out of 32 respondents or $12 \%$ stated that they agreed with statements that showed low entrepreneurial attitudes. Thus it can be said that the entrepreneurial attitude of Padang PK PK course participants is low.

For more details, then we can consider the description of participants in Padang City PK courses in Figure 1.

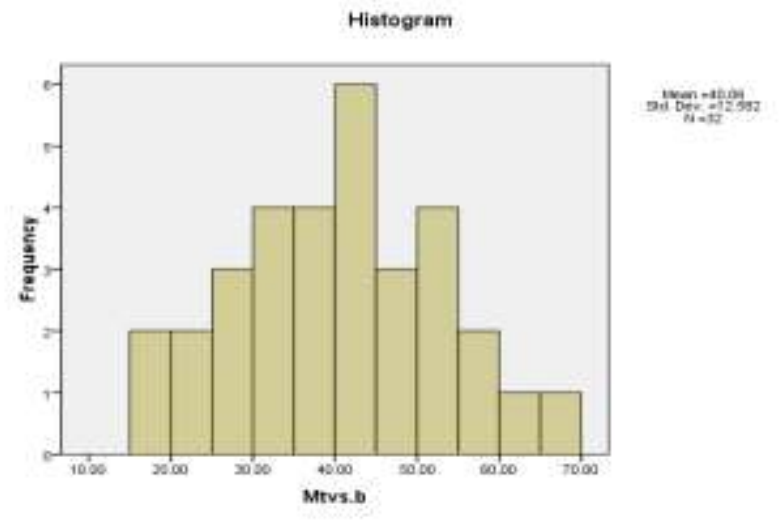

Figure 1

Entrepreneurship Attitudes Participants in Padang City PK Course 


\section{B. Overview of Work Readiness of PK Course Participants in Padang}

Based on the result of the data analysis, we can conclude overview of the work readiness of Padang City PK course participants, look at the Tabel 2.

Table 2

Overview of Work Readiness of PK Course Participants in Padang

\begin{tabular}{|c|c|l|c|c|}
\hline No. & $\begin{array}{c}\text { Skor } \\
\text { interval }\end{array}$ & \multicolumn{1}{|c|}{ Criterion } & Frequency & $\%$ \\
\hline 1 & $55-68$ & Very high & 5 & 16 \\
2 & $41-54$ & high & 9 & 27 \\
3 & $27-40$ & low & 14 & 44 \\
4 & $13-26$ & very low & 4 & 13 \\
\hline \multicolumn{5}{|r}{ total } \\
\hline \multicolumn{4}{|r}{}
\end{tabular}

From the Table 2, illustrated that the work readiness of Padang PK PK course participants is low. This is evidenced by the small number of respondents, namely 5 people out of 32 respondents or $16 \%$ who stated that they agreed with statements that showed high work readiness. On the other hand, only 14 out of 32 respondents or $44 \%$ stated that they agreed with statements indicating low work readiness. Thus it can be said that the work readiness of Padang PK course participants is low.

For more details, we can see overview of the work readiness of Padang City PK course participants in the following Figure 2.

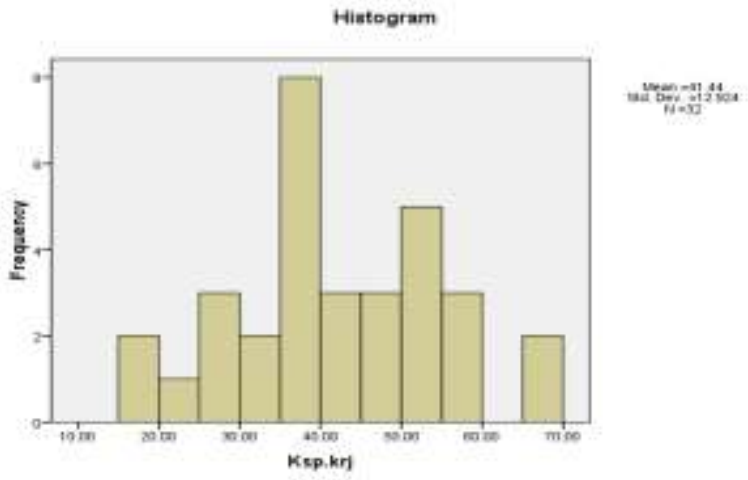

Figure 2

Overview of Work Readiness of PK City Participants in Kota Padang

\section{The Correlation Between Entrepreneurship Attitudes and Work Readiness of PK Course Participants in Padang}

The simple regression requirements assumption and hypothesis testing are presented first. Test the Assumption of Simple Regression Requirements. Before the data is analyzed using simple regression analysis techniques (simple regression), assumption tests are first performed as a requirement in simple regression analysis techniques (simple regression). According to Sudarmanto (2005) the tests are normality test, linearity test, homogeneity test, multicollinearity test, autocorrelation test, and heteroscedasticity test. Each is explained as follows.

Normality test is done to find out whether the data distribution follows or approaches the normal distribution. Therefore, good data is data that has a normal or near normal distribution pattern. Based on the normality test, when viewed from the distribution of data in the QQ plot, the data are clustered in the test line and pointing to the upper right. In this connection, regression is appropriate to be used to analyze the data.

Homogeneity test is performed to detect the presence or absence of homogeneity, used to see the spread of points (points) on the graph. If the points spread and do not form a certain pattern, then the data is said to be homogeneous [12]. If seen from the resulting graph found random points, it can be concluded that the data distribution is homogeneous. Thus, the analysis is worth proceeding.

Linearity test is done in pairs between each independent variable and the dependent variable. In this case the linearity of the relationship between the independent variables of achievement motivation and the dependent variable work readiness will be seen. Linearity tests are carried out by comparing compare means analysis by comparing the significance value with the chosen alpha level (here 5\%). Data is said to be linear because it is significant for deviation from linearity $>$ of the given alpha.

Based on the results of data analysis of the scater plot, a regression line can be seen on the graph of each variable leading to the upper right. Thus, it can be concluded that the relationship between the dependent variable and the independent variable is linear. Therefore, regression analysis can be used.

\section{The result of Hypothesis testing}

Simpel regression analysis in this study is used to (a) look at the relationship between independent variables, namely entrepreneurial attitudes $(\mathrm{X})$ with work readiness (Y); and (b) Looking at the contribution of independent variables to the dependent variable. For the purposes of analysis computer assistance with SPSS for Window Release 16.0 is used. The results of the hypothesis test can be stated as follows.

The hypothesis is formulated in the form of a working hypothesis (Ha) which reads, "There is a significant relationship between entrepreneurial attitudes and job readiness of participants in the Padang City Vocational Education (PK) course". To test this hypothesis, the results of the Pearson correlation analysis (r) are used. The correlation analysis results (r) obtained were 0.794 with a significance level of 0.000 or smaller than the tolerance given 0.05. Based on such calculations, the null hypothesis (Ho) is rejected. This means that entrepreneurship attitudes (X) have a significant relationship with job readiness $(\mathrm{Y})$ of the Padang City Vocational Education (PK) course participants.

The description of the probability correlation coefficient can be seen in the following Table 3.

Table 3

Overview of Work Readiness of PK Course Participants in Padang

\begin{tabular}{|l|l|l|l|}
\hline Variable & $\begin{array}{c}\text { Coeficient } \\
\text { Correlation (R) }\end{array}$ & Probability & Description \\
\hline $\mathrm{X} \rightarrow \mathrm{Y}$ & 0,794 & 0,000 & Significant \\
\hline
\end{tabular}

Description:

(X) $\quad=$ Achievement Motivation

(Y) $\quad=$ Jobreadiness 
The second hypothesis, formulated in the form of a working hypothesis (Ha) which reads, "Entrepreneurial attitude $(\mathrm{X})$ has a significant contribution to work readiness (Y) for Skills Education (PK) course participants. To see the magnitude of the contribution of the independent variable entrepreneurial attitude $(\mathrm{X})$ to job readiness $(\mathrm{Y})$ participants of the Padang City Vocational Education (PK) course, it will be seen from the large value of Adjusted R Square in the Sumery Model table. To test the amount of the contribution if the independent variable is more than two, the Adjusted $\mathrm{R}$ Square value [11] should be used. From the summery model table, it is found that the value of Adjusted $\mathrm{R}$ Square is 0.639 with a significance of 0.000 . This means that the independent variable of entrepreneurial attitudes (X) provides a significant contribution of $0.618(61.8 \%)$ to the dependent variable of work readiness (Y) for participants in the Padang City Vocational Education (PK) course.

\section{E. Test the Regression Equation Coefficient}

For the sake of the regression equation coefficient test can be seen in the results of the regression analysis illustrated in table 4 . In table 4 the regression coefficient test table obtained 8.760 constant coefficients. The coefficient of entrepreneurial attitudes (X) 0.816 . Therefore, the regression equation model is $\mathrm{Y}=8.760+$ $0.816 \mathrm{X}$. For more details, see Table 4.

Table 4

Regression Equation Coefficient Test Results

\begin{tabular}{|c|c|c|c|c|c|c|}
\hline \multicolumn{2}{|c|}{ Model } & \multicolumn{2}{|c|}{$\begin{array}{c}\text { Unstandardized } \\
\text { Coefficients }\end{array}$} & $\begin{array}{c}\text { Standardized } \\
\text { Coefficients }\end{array}$ & \multirow{2}{*}{ T } & \multirow{2}{*}{ Sig. } \\
\cline { 3 - 5 } & B & $\begin{array}{c}\text { Std. } \\
\text { Error }\end{array}$ & Beta & & \\
\hline 1 & (Constant) & 8,760 & 4,779 & & 1,833 &, 000 \\
\hline 2 & $\begin{array}{c}\text { Motivasi } \\
\text { berprestasi (X) }\end{array}$ & 0,816 & 0,114 & 0,794 & 7,156 &, 000 \\
\hline
\end{tabular}

Dependent Variable in Jobreadiness (Y)

\section{CONCLUSION AND SUGGESTION}

In this concluding chapter (a) the conclusions of the results of the study and (b) suggestions. Conclusions are drawn based on research findings and discussion. Next, based on the research findings and discussion, several suggestions are proposed.

In conlusion, research findings illustrate that entrepreneurial attitudes of PK course participants in the Sanggar PK Learning Activity in Kota Padang are low. In connection with the low attitude of entrepreneurship, the learning activities they are not motivated to master the knowledge and skills provided to them as a provision to face life in the form of readiness to face competition getting increasingly stringent employment through entrepreneurship.

Second, the research findings illustrate that the work readiness of PK course participants in the Padang City Learning Activity Studio is low. The low work readiness of the course participants, in addition to being related to entrepreneurial attitudes, as stated in point one, this is possible because course participants learn more to obtain certificates than to master knowledge and skills that can be used to navigate life.

Third, entrepreneurial attitude has a significant relationship with job readiness of participants in the Skills Education Course (PK) of the Padang City Learning Activity Center, this is evident from the magnitude of the correlation number ( $r$ ) and the magnitude of the significance price (sig) found. This means that if entrepreneurship attitudes are improved for the better, the job readiness of the participants of the Sanggar Education Study Program (PK) of the Padang City Learning Activities will get better or vice versa if the entrepreneurial attitude is low, it will result in weaker work readiness of the Sanggar Vocational Education (PK) course participants. Padang City Learning Activities.

Lastly, entrepreneurial attitudes have a significant contribution to the work readiness of Skills Education (PK) course participants. That is, if you want to increase the work readiness of participants of the Skills Education (PK) course in the Padang City Learning Activities Studio, then their entrepreneurial attitude must be increased first. That is because in improving work readiness, entrepreneurship attitude is a variable that needs to be taken into account, including for participants in the Padang City Vocational Education (PK) course.

\section{REFERENCES}

[1] M. N. Almasri, "Manajemen Sumber Daya Manusia: Implementasi dalam Pendidikan Islam," Kutubkhanah J. Penelit. Sos. keagamaan, vol. 19, no. 2, pp. 133-151, 2016.

[2] A. Sujanto, "Pengembangan Kemitraan Lembaga Kursus dan Pelatihan (LKP) dengan Dunia Usaha dan Dunia Industri (DUDI) Untuk Penjaminan Mutu LKP," INFOKAM, vol. XII, no. 1, pp. 59-65, 2016.

[3] I. Hanafi, "Re-Orientasi Keterampilan Kerja Lulusan Pendidikan Kejuruan," J. Pendidik. Vokasi, vol. 2, no. 1, pp. 107-116, 2012.

[4] E. Fauzia, "Pengaruh Prestasi Belajar dan Motivasi Berprestasi Terhadap kKesiapan Berwirausaha Pada sSiswa SMK Negeri 1 Cerme Gresik," J. Ekon. Pendidik. dan Kewirausahaan, vol. 1, no. 1, pp. 53-65, 2013.

[5] Kuntowicaksono, "Pengaruh Pengetahuan Wirausaha dan Kemampuan Memecahkan Masalah Wirausaha Terhadap Minat Berwirausaha Siswa Sekolah Menengah Kejuruan," J. Econ. Educ., vol. 1, no. 1, pp. 45-52, 2012.

[6] S. P. Aji, H. Mulyadi, and B. Widjajanta, "Keterampilan Wirausaha Untuk Keberhasilan Usaha," J. Bus. Manag. Educ., vol. 3, no. 3, pp. 111-122, 2018.

[7] Y. G. D. U. dan Hudaniah, "Self Efficacy dengan Kesiapan Kerja Siswa Sekolah Menengah Kejuruan," J. Ilm. Psikol. Terap., vol. 01, no. 01, pp. 40-52, 2013.

[8] R. D. Baiti, S. M. Abdullah, and N. S. Rochwidowati, "Career Self-Efficacy Dan Kesiapan Kerja Pada Mahasiswa Semester Akhir," J. Psikol. Integr., vol. 5, no. 2, pp. 128 $141,2017$.

[9] J. A. N. Deas Bella Rosara, Harini, "Pengaruh Pengalaman Praktik Kerja Industri dan Motivasi Memasuki Dunia Kerja terhadap Kesiapan Kerja Peserta Didik SMK Kristen 1 Surakarta Tahun Angkatan 2017/2018," BISE J. Pendidik. Bisnis dan Ekon., vol. 4, no. 1, pp. 1-14, 2018.

[10] G. Sudarmanto, Analisis Regresi Linier Ganda dengan SPSS. Yogyakarta: Graha Ilmu, 2005.

[11] S. Santoso, Statistik Parametrik. Jakarta: PT Elek Media Komputindo, 2010. 